\title{
Sciendo
}

\section{O Paradoxo da Pergunta}

Ned Markosian

West Virginia University

Disputatio No. 1

December 1996

DOI: $10.2478 /$ disp-1996-0003

ISSN: 0873-626X 


\title{
O PARADOXO DA PERGUNTA*
}

\author{
Ned Markosian
}

Era uma vez uma grande conferência internacional com os mais reputados filósofos, na qual, miraculosamente, apareceu um anjo que disse: «Venho até vós como mensageiro de Deus. Ser-vos-á dada a oportunidade de fazer qualquer pergunta que desejem — mas apenas uma! —, cuja resposta verdadeira vos facultarei. Que desejam perguntar?» Os filósofos ficaram compreensivelmente excitados, e começaram de imediato a discutir qual seria a melhor pergunta a fazer. Mas rapidamente se tornou evidente que precisavam de mais tempo; pediram portanto ao anjo que voltasse mais tarde. $\mathrm{O}$ anjo era bastante prestável, de maneira que prometeu regressar à mesma hora no dia seguinte. «Mas é bom que nessa altura estejam preparados — avisou-os —, pois não terão outra oportunidade.»

Todos os filósofos presentes na convenção trabalharam freneticamente nas vinte e quatro horas seguintes, propondo e ponderando os méritos de várias perguntas. Filósofos de todo o mundo participaram igualmente, enviando as suas sugestões por fax e por correio electrónico. Alguns filósofos eram a favor de se fazer o tipo de pergunta prática cuja resposta muitas pessoas gostariam de saber, como esta:

P1 É melhor ver o óleo do carro quando ele está quente, ou quando está frio?

Mas outros filósofos disseram que não deviam desperdiçar esta oportunidade rara, que lhes dava a possibilidade de aprenderem qualquer coisa sobre um tópico verdadeiramente importante e intrinsecamente interessante, o que, depois de alguma discussão, acabou por ser em geral aceite.

Os filósofos estavam no entanto sem saber sobre que tópico verdadeiramente importante e intrinsecamente interessante devia ser a pergunta. $\mathrm{O}$ problema era que precisavam de saber à partida qual seria a melhor pergunta a fazer, de maneira a tirar o maior partido desta maravilhosa oportunidade.

\footnotetext{
* Artigo a publicar no número de Janeiro de 1997 de Analysis, a cujo Director, Peter Smith, disputatio agradece.
}

disputatio, 1, Dezembro 1996 
Uma das propostas era tentar introduzir sub-repticiamente duas perguntas, perguntando qualquer coisa como:

P2 Qual seria a nossa melhor pergunta, e qual é a resposta a essa pergunta?

Mas esta proposta foi rapidamente recusada, assim que se fez notar que o anjo tinha dito explicitamente que só tinham direito a uma pergunta.

Outra das propostas era fazer apenas a primeira das perguntas de P2, na esperança de um dia virem a ter outra oportunidade semelhante a esta, altura em que poderiam então fazer a pergunta que saberiam ser a melhor. Esta proposta foi recusada, contudo, uma vez que era provável que nunca chegassem a poder fazer a melhor pergunta, depois de saberem qual era.

Numa certa altura, começou a gerar-se um consenso crescente segundo o qual se devia fazer a seguinte pergunta:

P3 Qual é a resposta à pergunta que seria a melhor pergunta a fazer?

Desta forma, argumentava-se, teriam pelo menos a informação maximamente importante contida na resposta relevante. Mas os filósofos acabaram por ficar preocupados com a possibilidade de receberem, em resposta a P3, uma resposta como «sete», ou «sim», que não teria para eles qualquer significado, a não ser que soubessem que pergunta estava a ser respondida.

Por fim, quando os filósofos já estavam a ficar sem tempo, um jovem lógico inteligente fez uma proposta que foi rápida e esmagadoramente aprovada. Eis a sua pergunta:

P4 Qual é o par ordenado cujo primeiro membro é a melhor pergunta que poderíamos fazer-lhe, e cujo segundo membro é a resposta a essa pergunta?

Quase toda a gente (não esqueçamos que se trata de filósofos) concordava que esta era a maneira ideal de resolver o pequeno problema com que se confrontavam. Ao perguntar P4, os filósofos asseguravam que ficariam a saber simultaneamente qual era a melhor pergunta a fazer, e qual era a sua resposta. Os filósofos comemoraram e congratularam-se mutuamente, e, à medida que se aproximava a altura em que o anjo tinha prometido regressar, havia entre os filósofos do mundo inteiro uma expectativa quase febril. 
Toda a gente estava excitada com a perspectiva de aprender uma verdade magnífica e importante. Estavam também razoavelmente satisfeitos consigo mesmos por terem conseguido encontrar uma maneira tão inteligente de resolver o problema de saber qual seria a melhor pergunta, conseguindo obter também a sua resposta, quando apenas podiam fazer uma única pergunta.

Foi então que o anjo regressou. Os filósofos fizeram a sua pergunta solenemente - $\mathrm{P} 4-\mathrm{e}$ o anjo ouviu com atenção, dando depois a sua resposta:

R4 É o par ordenado cujo primeiro membro é a pergunta que me fizeram, e cujo segundo membro é esta resposta que vos estou agora a dar.

Assim que respondeu, o anjo desapareceu, deixando os filósofos a arrancar os cabelos com a frustração.

Esta história deixa-nos com outro pequeno problema para resolver. $\mathrm{Na}$ altura em que os filósofos perguntaram P4, esta parecia, naquela situação peculiar, a pergunta ideal. Mas acabou por tornar-se claro que P4 não era de forma alguma a melhor pergunta a fazer. (Mais valia que tivessem perguntado se devemos verificar o óleo do carro quando ele está quente ou quando está frio.) O problema é, então, este: o que é que correu mal? ${ }^{1}$

(Tradução de Desidério Murcho)

\section{Ned Markosian}

Department of Philosophy

West Virginia University

Morgantown, WV 26506-6312, USA

nmarkos@wvnet.edu

\footnotetext{
${ }^{1}$ Agradeço a Mark Aronszajn e a Donald Turner as discussões sobre este tópico e a Donald Turner por me ter contado a piada na qual o problema se baseia.
} 